\title{
会話参加者によるFTA 軽減ストラテジーの使用実態
}

一日本語母語話者と中国語母語話者の場合一

\section{A Study on the Use of FTA Redress Strategies of Speakers in Conversation}

- Japanese Native Speakers and Chinese Native Speakers-

許 夏玲

東京学芸大学留学生センター

\section{要旨}

本研究では、日常会話において、話し手が聞き手に対しFTA を行った場合、聞 き手がどのように言語表現とストラテジーを用いて自分への負担を軽減するか、 また話し手が自分自身に対しFTA を行った場合、聞き手がどのように言語表現と ストラテジーを用いて相手への負担を軽減するかを考察し、FTA の負担を軽減する ためのストラテジーの使用実態を明らかにすることを目的とする。また、言語や 文化習慣によってFTA 軽減ストラテジーの使用に違いが見られるかも考察したい。 考察の結果、FTA の状況におちいる際、笑い（両言語母語話者）及びフィラー（日 本語母語話者）が多く用いられるがわかった。笑いは、会話参加者の負担や状況 を和らげる機能を持ち、フィラーは、言いよどみの位置（文頭や文中）に多く現 れ、話し手の応答に対する時間を稼ぐ機能を持つと考えられる。本研究は、対照 言語研究の観点から中国語と日本語の表現の使用実態を分析することにより、相 互理解を深めると同時に、日本語会話の指導に役立てることが期待できる。

キーワード :

会話参加者、FTA 軽減ストラテジー、対照言語研究、ポライトネス、フェイス 


\section{会話参加者による FTA 軽減ストラテジーの使用実態 \\ 一日本語母語話者と中国語母語話者の場合-}

許 夏玲

東京学芸大学留学生センター

\section{1. 研究動機}

文法上一見正しいと判断される表現であっても、実際の発話場面で用いられる と、不適切な表現と判断されることがある。たとえば、次の例文の(1) と (2)を見 てみよう。

（1）请你考虑一下吧。（？ちょっと考えてください。）

（2）我也不明白, 你问一问别人吧。（？私もわからないので、ほかの人にちょっと 聞いてください。）

(1a）ちょっと考えてみたら?

（1b）ちょっと考えていただけますか。

(2a）私もわからないので、ほかの人にちょっと聞いてみたら?

（2b）私もわからないので、ほかの人にちょっと聞いてみていただけますか。

上記の例文 (1) と（2）の中国語の表現は、話し手が相手に対して丁寧に依頼して いるのに対し、「请/吧」を日本語の「ーてください」に直訳すると、相手の行動 を指示する表現になり、場合により相手に押し付けがましい印象を与えてしまう おそれがある。（1）と（2）の表現は（1a）（1b）と（2a）（2b）のような表現に言い換える と、落ち着きがよくなる。

このように、情報要求、依頼、申し出などの場合に、話し手が相手の私的領域 に立ち入り、相手に失礼な印象を与えるおそれがある。いかに相手との人間関係 を友好に維持しながら、会話のゴールを達成するかは、言語運用能力を高めるた めの重要な日本語会話教育の課題の一つであろう。

三牧 (2008) は、日本語母語話者の会話データに基づいて、談話全体のマクロ的 観点から FTA（フェイスを驾か寸行為 Face Threatening Act，以下FTA と呼ぶ） のやりとりの推移を談話の展開とともに分析し、FTA 遂行後の寸でに侵害されたフ エイスの参加者間のアンバランスを是正するための参加者の相互行為を論じた。 フェイスは、他者に認められたいというポジティブ・フェイス (positive face) と、他者に邪魔されたくないというネガティブ・フェイス（negative face）の 2 つに分けられる。しかし、対照言語研究の観点から日中両言語の日常会話におけ 
るFTA及びその軽減ストラテジーに関する研究は管見の限りまだなされていない。 対照言語研究の観点から中国語と日本語の表現の使用実態を分析することにより、 相互理解を深めると同時に、日本語会話の指導に役立てることが期待できる。

\section{2. 研究目的}

本研究では、日本語の会話において、会話参加者である話し手が同じ会話参加 者である聞き手に対しFTA を行った場合、聞き手がどのように言語表現とストラ テジーを用いて自分への負担を軽減するか、また話し手が自分自身に対しFTA 行った場合、聞き手がどのように言語表現とストラテジーを用いて相手への負担 を軽減するかを自由会話データに基づいて考察し、日常会話における FTA の負担 を軽隇するためのストラテジーの使用実態を明らかにすることを目的とする。ま た、言語や文化習慣によってFTA軽減ストラテジーの使用に違いが見られるかを、 日本語母語話者及び中国語母語話者の会話データから考察したい。

\section{3. 研究方法}

会話データは、許 (2010)の「話し言葉の研究 CD-ROM」のデータベースを使用し た。会話の協力者は、東京に住んでいる日本人大学生と中国人大学生である。日 本語母語話者同士の親疎各 2 組及び中国語母語話者同士の親疎各 2 組合計 8 組を 対象に、15 分間の自由会話、合計 120 分の会話データをもとに考察した。会話協 力者を親疎両グループに分けるのは親疎関係による表現とストラテジーの違いを 見るためである。疎のグループの会話同士は、初対面同士ではなく、同じ専攻の 先輩と後輩の関係で面識がある程度である。

\section{4. ポライトネスについて}

ポライトネス (politeness) は Brown \& Levinson(1987)で取り上げられている用 語である。日本語の丁寧表現、敬語表現などに限られていない。次の例文の (3)の ように、命令形を用いたほうがその会話の場面により適切であると考えられる場 合もある。また、例文の (4)のように、親しい仲間の間で敬語表現を用いると、相 手に咒談っぽく、または皮肉っぽく言っている印象を与える。

（3）（男性同僚でお酒を勧める時）もっと飲め、飲め。

（4）（相手にうるさく言われて）はい、かしこまりました。 


\section{許 夏玲：会話参加者による FTA 軽減ストラテジーの使用実態}

一日本語母語話者と中国語母語話者の場合一

Brown \& Levinson(1987)では、ポライトネスを「円滑な人間関係を確立・維持 するための言語的ストラテジー」と定義している。また、人間の基本的欲求は、 ポジティブ・フェイス（positive face）、すなわち他者に理解されたい、好かれ たい、認められたいというプラス方向に関わる欲求とネガティブ・フェイス (negative face)、すなわち他者に邪魔されたくない、立ち入られたくないという マイナス方向に関わる欲求の 2 つに分けられる。この 2 つのフェイスを脅かさな いように配慮することがポライトネスであるという。

\section{FTA と見なすものは何か}

本研究では、ポジティブ・フェイス及びネガティブ・フェイスを劦かさす言語 行動をFTA と見なし、次の表 1 の通り、FTAを他者向けの FTA 及び自己向けの FTA の 2 種類に分けて分析を進めていきたい。また、次の図 1 のように、会話におい て、話し手が聞き手に対し FTA（ポジティブ・フェイスまたはネガティブ・フェイ ス)を行った場合、聞き手が自分のフェイスへの負担を軽減するため、ポジテイ ブ・フェイスまたはネガティブ・フェイスを補償する言語表現とストラテジーを 用いると考える。また話し手が自分自身に対し FTA（ポジティブ・フェイス）を行 った場合、聞き手が仲間意識を高めるため、相手のポジティブ・フェイスを補償 する言語表現とストラテジーを用いると考える。

\section{表 1 FTA の分類}

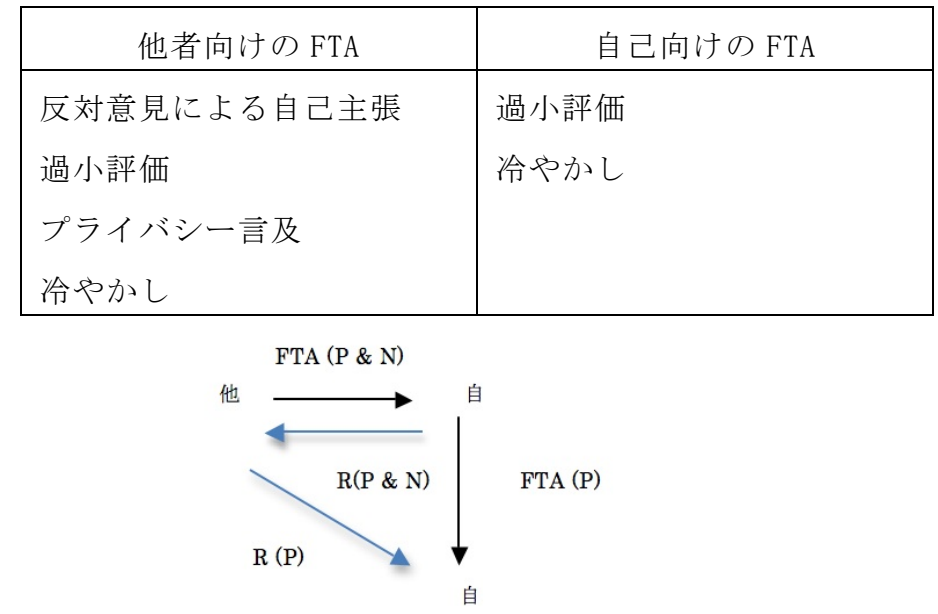

図 1 FTA 軽減ストラテジーの使用状況

$\mathrm{P}$ : positive face, $\mathrm{N}$ : negative face, $\mathrm{R}$ : remedial strategies 


\section{6. 会話データに基づく考察結果 \\ 6. 1 他者向けの FTA \\ 6. 1.1 反対意見による自己主張}

相手と反対の意見による自己主張は、相手に理解されたい、認められたいとい う相手のポジティブ・フェイスを劦かす言語行動になるため、相手に失礼な印象 を与えてしまうことがある。（以下、中国語の例文の日本語訳に関しては付加資料 を参照されたい。）

（5）日本語母語話者同士（親）

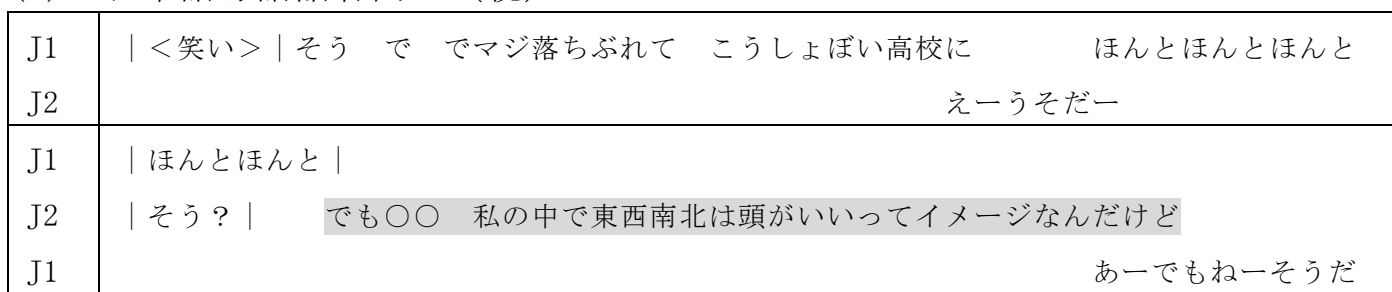

発話の重なり

（6）中国語母語話者（疎）

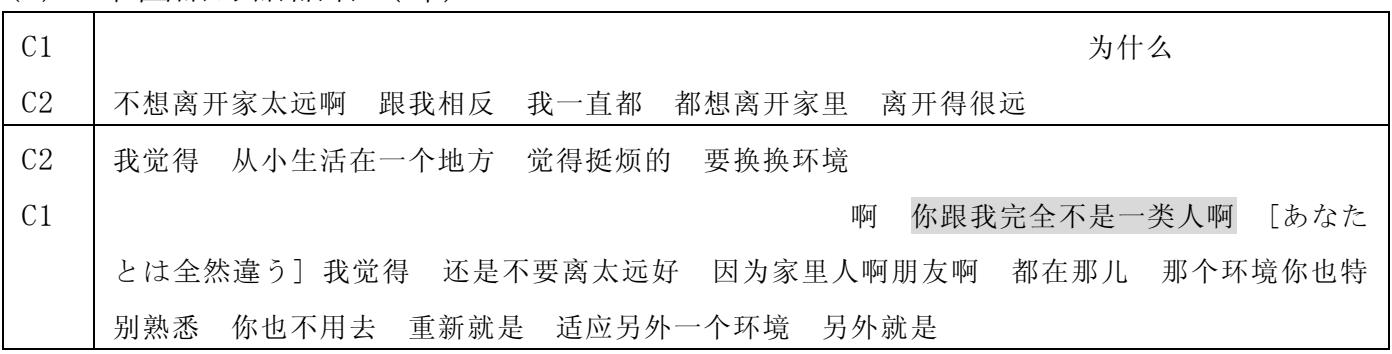

\section{1.2 過小評価}

相手に理解されたい、認められたいという人間の基本的欲求があるため、相手 の能力や容姿など相手に関わることを過小に評価すると、相手のポジティブ・フ エイスへの負担をかけることになると考えられる。

（7） 中国語母語話者（親）

\begin{tabular}{|c|c|c|c|}
\hline $\mathrm{C} 1$ & 对啊 我跟我妈说 & 我 你可能不知道什么是棉裤吧 & [あったかパンツなんて知らないよ対] \\
\hline $\mathrm{C} 2$ & 恩 & & \\
\hline $\mathrm{C} 1$ & & そうそうそうく笑＞棉裤 & \\
\hline $\mathrm{C} 2$ & 棉裤就是穿在那个裤子 & 里面的 <笑 $>$ & \\
\hline
\end{tabular}




\section{許 夏玲：会話参加者によるFTA 軽減ストラテジーの使用実態}

一日本語母語話者と中国語母語話者の場合-

（8）日本語母語話者（疎）

\begin{tabular}{|c|c|c|c|c|}
\hline J1 & ＜笑い> & & \multicolumn{2}{|l|}{ あ } \\
\hline $\mathrm{J} 2$ & ＜笑い> & 3 年になると今後期 & あーもう 4 コマしか & \\
\hline J1 & | そんなもんですか & ヘー & | あ一ちゃんと取ってると | & なるほど \\
\hline J2 & | ないからー| & まあ ちゃちゃんと & | 取ってましたから＼cjkstart笑い>| & \\
\hline
\end{tabular}

\section{1.3 プライバシー言及}

人間は、相手に邪魔されたくない、立ち入られたくないというネガティブ・フ エイスを持っている。相手との親疎関係に関わらず、話し手が相手の家族、恋人、 過去などの私的領域に言及すると、相手に負担をかけてしまうため、失礼になる。 しかし、親しい仲間同士の間では、私的領域に立ち入る話が多く見られるが、私 的領域に立ち入る度合いは、その仲間同士の付き合いによって違うと考えられる。

（9）日本語母語話者同士（親）

\begin{tabular}{|c|c|}
\hline J1 & （クリスマスプレゼントについて）｜一年目は? | \\
\hline $\mathrm{J} 2$ & |でも| \\
\hline J1 & | じゃあ一年目から教えて | \\
\hline $\mathrm{J} 2$ & | いやちょっと｜ \\
\hline J1 & $\mid<$ 笑い> $\mid$ \\
\hline $\mathrm{J} 2$ & $\begin{array}{l}\text { | でもほんとに一なんか意外とそういうものって|なんかあんまり一ないんだよね けっこう } \\
\text { だから }\end{array}$ \\
\hline
\end{tabular}

（10） 中国語母語話者（親）

\begin{tabular}{|c|c|c|c|}
\hline \multirow{3}{*}{$\begin{array}{l}\mathrm{C} 1 \\
\mathrm{C} 2\end{array}$} & \multicolumn{2}{|c|}{ 哎? } & 高中我带了 15 天 $<$ 笑 $>$ \\
\hline & 那你是一直在高中啊 & 一直在教高中啊 & 你就不干了？ \\
\hline & & & [もうやめたの? ] \\
\hline $\mathrm{C} 1$ & 不干了 $<$ 笑 $>$ & $<$ 笑 $>$ & \\
\hline $\mathrm{C} 2$ & & 害了<笑> & \\
\hline
\end{tabular}

\section{1.4 冷やかし}

今回の収集したデータでは、相手との関係が親疎に関わらず、話が進んでい くうち、話し手が相手の能力など相手に関わることを、ジョークを混じって冷や 
かす用例が見られた。これは会話参加者の間に考えのずれが生じるところに現れ や寸い傾向がある。冷やかしは、相手のポジティブ・フェイスに負担をかける言 語行動になる。

（11）日本語母語話者同士（親）

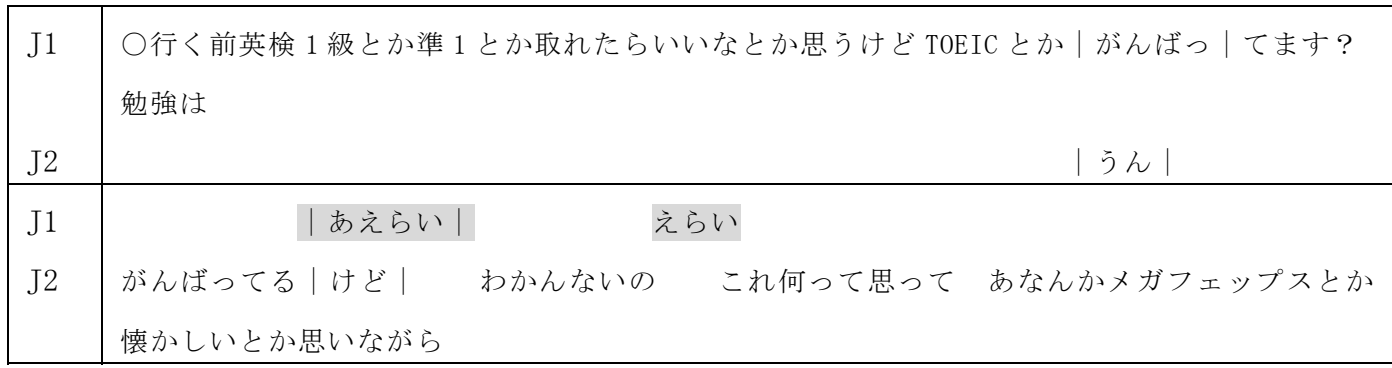

（12）中国語母語話者（疎）

\begin{tabular}{|c|c|}
\hline $\begin{array}{l}\text { C1 } \\
\text { C2 }\end{array}$ & 自己租房子有那么辛苦 然后学习吧 他们学的也是跟我们交换留学生一样的课程 你说学的话 \\
\hline $\mathrm{C} 1$ & 唉 都不知道干嘛 就这样 就觉得好盲目 \\
\hline $\mathrm{C} 2$ & 对 我觉得交换留学和就是在这个地方就是住在这里 \\
\hline $\mathrm{C} 1$ & 嗯嗯 \\
\hline \multirow[t]{2}{*}{$\mathrm{C} 2$} & 拿这里的签证的那种感觉还是不太一样 交换留学就是有一种 反正我就是过来体验体验 \\
\hline & [交換留学ってどうせここに来てちょっと体験してみるだけ］ \\
\hline $\mathrm{C} 1$ & 对 我就是这样 <笑 $>$ \\
\hline $\mathrm{C} 2$ & 一年就回去了＜笑＞［1年でもう帰る］ \\
\hline
\end{tabular}

今回、収集したデータに基づいて考察した結果、親しくない間柄の中国語母語 話者同士では、共有認識を持っていない場合、反対意見による自己主張の用例が 多く見られた。過小評価は、日本語母語話者及び中国語母語話者の親しくない間 柄同士では、互いの認識が十分に得られていないために行われやすいと考えられ る。親しい間柄同士になると、相手の私的領域にどのくらい立ち入ることが許さ れるのか、そのボーダーラインが明確ではないため、日本語母語話者及び中国語 母語話者の親しい間柄同士では、プライバシー言及の FTA が行われやすい傾向が ある。 


\section{許 夏玲：会話参加者によるFTA 軽減ストラテジーの使用実態}

一日本語母語話者と中国語母語話者の場合一

\section{2 自己向けの FTA}

\section{2.1 過小評価}

過小評価は、親しくない間柄同士では行われる傾向が見られる。話し手があま り親しくない相手の前で自分の能力など、自分のことを過小に評価することによ り、謙遜な気持ちを表すことができると考えられる。

\section{（13） 中国語母語話者（疎）}

\begin{tabular}{|l|l|l|}
\hline $\mathrm{C} 1$ & & \\
$\mathrm{C} 2$ & 然后 找了很多都没找到 后面是 师姐 师姐 以前在一家店打工 然后 她跟她老板认识 \\
& 然后就 跟老板说一下 \\
$\mathrm{C} 1$ & 我 & \\
$\mathrm{C} 2$ & 然后 我就可以进去了 我觉得挺丢脸的 [不器用でけっこう恥ずかしかったと思う] \\
\hline C1 & 我是自己找的 但是 但是 找的那个离车站特别特别远 要走二十多分钟路 \\
$\mathrm{C} 2$ & & \\
\hline
\end{tabular}

\section{2 .2 冷やかし}

親疎関係に関わらず、話し手が自分のフェイスを劦かされそうな状況で自分の ことや言動を冷やかすことにより、自分のフェイスへの負担を幾らか軽減するこ とができると考えられる。

今回のデータを見ると、親しい日本語母語話者同士の場合、話し手が自分に対 して過小評価を行い、親しくない同士では話し手が自分に対して冷やかしを行う 用例が多く見られた。中国語母語話者同士の場合、親疎に関わらず、話し手が自 分に対して冷やかしを行う傾向が見られなかった。

（14）日本語母語話者同士（疎）

\begin{tabular}{|c|c|}
\hline $\begin{array}{l}\mathrm{J} 1 \\
\mathrm{~J} 2\end{array}$ & $\begin{array}{c}\text { 今日 } 2 \text { 限の○[科目名]が去年＼cjkstart落とされてーでも久しぶりに行ったわとか言って } \\
\qquad \text { 笑い> }\end{array}$ \\
\hline $\begin{array}{l}\mathrm{J} 1 \\
\mathrm{~J} 2\end{array}$ & てかもう一人取ってるのがいるんですけどー $\begin{aligned} \text { て笑い }>\end{aligned}$ \\
\hline J1 & $\begin{array}{l}\text { このまえの○[科目名]行ったー?って言ったら 行ってないけどさー そろそろ私マズいかな } \\
\text { って んー 私もマズいと思うとか言ってく笑い> }\end{array}$ \\
\hline $\begin{array}{l}\mathrm{J} 2 \\
\mathrm{~J} 1\end{array}$ & 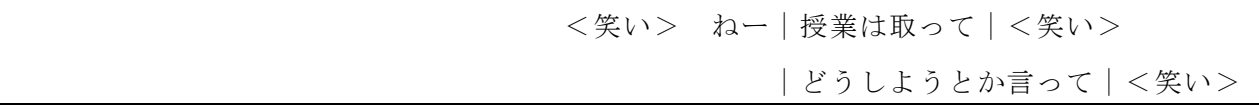 \\
\hline
\end{tabular}




\section{3 FTA の用例数}

本研究の会話データを考察した結果、FTAの用例数は次の表 2 にまとめられる。 日本語母語話者の場合、親しくない相手に自分の反対意見を出さない、また相手 のプライバシーに言及しない傾向が見られる。一方、親しくない相手に仲間意識 を高めてもらうためか、話し手が自分のことを冷やかすことが多いようである。 中国語母語話者の場合、親しくない相手のプライバシーに言及しないという点で は日本語母語話者と共通している。しかし、相手のことをよく知らないためか、 親しくない相手に対しても自己を主張する傾向が見られる。一方、親疎に関わら ず、話し手が人前で自分のことを冷やかすことがあまりない。

\begin{tabular}{|c|c|c|c|c|}
\hline 表 2 FTA の用例数 & \multicolumn{2}{|c|}{ 他者向けFTA } & \multicolumn{2}{|c|}{ 自己向けFTA } \\
\hline FTA 分類 & \multicolumn{2}{|c|}{$\begin{array}{l}\text { 日本語母語話者 } \\
\text { 親（疎） }\end{array}$} & \multicolumn{2}{|c|}{$\begin{array}{l}\text { 中国語母語話者 } \\
\text { 親（疎） }\end{array}$} \\
\hline 反対意見による自己主張 & \multicolumn{2}{|l|}{$3(0)$} & \multicolumn{2}{|l|}{$2(5)$} \\
\hline 過小評価 & $1(5)$ & $9(4)$ & $2(4)$ & $4(4)$ \\
\hline プライバシー言及 & \multicolumn{2}{|l|}{$4(1)$} & \multicolumn{2}{|l|}{$3(0)$} \\
\hline 冷やかし & $4(2)$ & $1(6)$ & $1(2)$ & $0(1)$ \\
\hline
\end{tabular}

\section{4 他者向けの FTA の軽減ストラテジー}

データに基づいた考察結果は次のようにまとめられる。

\section{表 3 反対意見による自己主張の場合}

\begin{tabular}{|l|l|l|}
\hline 中国語母語話者（疎） & 日本語母語話者（親） & 中国語母語話者（親） \\
\hline 沈黙 & (笑い+）返答 & 話題回避 \\
問い返し+返答 & & 問い返し +笑い+返答 \\
話題回避 & & +笑い \\
笑い & & \\
\hline
\end{tabular}

Ikeda (2003) は、笑いはデリケートな情報を扱う場合の質問と応答及び会話維持 への協力に用いられると述べている。本研究では、伝達機能の観点から言葉を発 する発話のみではなく、音声を発する笑い及び音声を発しない沈黙も含めて発話 


\section{許 夏玲：会話参加者によるFTA 軽減ストラテジーの使用実態}

一日本語母語話者と中国語母語話者の場合-

とする。今回の考察結果を見ると、ポジティブな反応としての返答のほか、笑い という手段が多く用いられたことがわかった。一方、沈黙や話題回避については、 本研究ではネガティブな反応としての返答と見なしている。

（15）中国語母語話者同士（疎）【話題回避】（ネガテイブ）

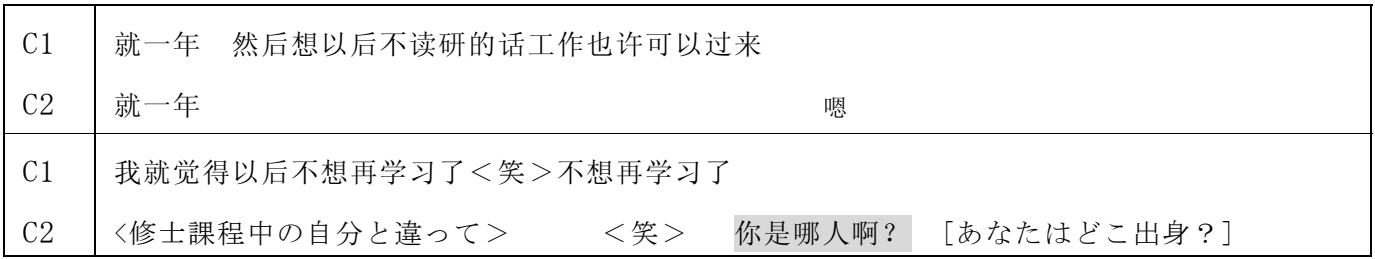

\section{表 4 過小評価の場合}

\begin{tabular}{|l|l|l|l|}
\hline $\begin{array}{l}\text { 日本語母語話者 } \\
(\text { 親 })\end{array}$ & $\begin{array}{l}\text { 中国語母語話者 } \\
\text { (親) }\end{array}$ & $\begin{array}{l}\text { 日 本語母 語話者 } \\
\text { (疎) }\end{array}$ & $\begin{array}{l}\text { 中国 語母 語話者 } \\
\text { (疎) }\end{array}$ \\
\hline $\begin{array}{l}(\text { 笑い+）返答 }+ \\
\text { 笑い }\end{array}$ & 返答 + 笑い & $\begin{array}{l}\text { 返答回避 }+ \text { 笑い } \\
\text { 返答 }+ \text { 笑い }\end{array}$ & $\begin{array}{l}\text { 話題回避 } \\
\text { 返答 }+ \text { 笑い }\end{array}$ \\
\hline
\end{tabular}

（16）日本語母語話者（疎）【返答十笑い】（ポジティブ）

\begin{tabular}{|c|c|c|c|c|c|}
\hline J1 & （J2 が! & 本語教育䏍 & 㫐力試験 & に落ちたことついて) & 難しい \\
\hline $\mathrm{J} 2$ & ( 2 秒) & あれは & たぶ & ん 2 回くらいやんないと & 受かんないね \\
\hline J1 & \multicolumn{5}{|c|}{ は一発|だったらしいですねく笑い>｜＜笑い> } \\
\hline $\mathrm{J} 2$ & 普通に & 【なまえ】 & ちゃん & あの & だったらしい|なんだろう／笑い $>$ \\
\hline
\end{tabular}

\section{表 5 プライバシー言及の場合}

\begin{tabular}{|l|l|l|}
\hline 日本語母語話者（親） & 中国語母語話者（親） & 日本語母語話者（疎） \\
\hline $\begin{array}{l}\text { 返答（十笑い） } \\
\text { 返答回避 }\end{array}$ & 返答回避 $(+$ 笑い $)$ & 笑い+返答 \\
\hline
\end{tabular}


（17）中国語母語話者同士（親）【返答回避＋笑い】（ネガティブ）

\begin{tabular}{|c|c|}
\hline $\mathrm{C} 1$ & 高中我带了１５天＜笑＞ \\
\hline $\mathrm{C} 2$ & \\
\hline $\mathrm{C} 1$ & $<$ 笑 $>$ \\
\hline $\mathrm{C} 2$ & 你太厉害了<笑 $>$ \\
\hline
\end{tabular}

\section{表 6 冷やかしの場合}

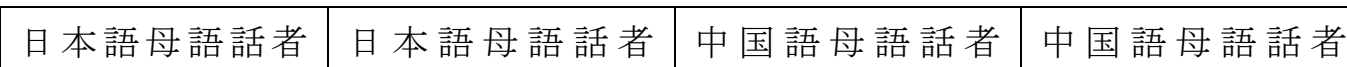

\begin{tabular}{|c|c|c|c|}
\hline （親） & (疎) & （親） & （疎） \\
\hline$($ 笑い十）返答 & $\begin{array}{l}\text { 笑い十フィラー } \\
\text { 返答回避＋笑い }\end{array}$ & 返答 & $\begin{array}{l}(\text { 笑い }+) \text { 返答 }+ \\
\text { 笑い }\end{array}$ \\
\hline
\end{tabular}

（18） 日本語母語話者（疎）【笑い十フィラー】（ネガティブ）

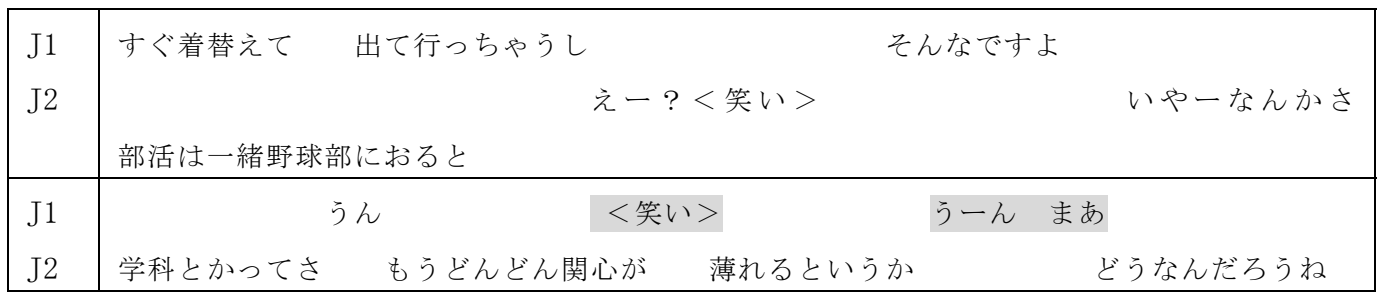

\section{5 自己向けの FTA の軽減ストラテジー}

話し手が自分自身に対し FTA を行った場合、もう一方の相手が話し手にポジテ イブな評価（話し手の下したネガティブな評価を否定することも含む）を提示し たり、同感を表したり、もしくは話し手より自分のほうが劣ることを表すことに よって話し手のことを持ち上げることで、会話を持続させ、仲間意識を高めよう とすることが今回のデータに基づいて考察された。

\section{表 7 過小評価の場合}

\begin{tabular}{|c|c|c|c|}
\hline $\begin{array}{l}\text { 日本語母語話者 } \\
\text { (親) }\end{array}$ & $\begin{array}{l}\text { 中国語母語話者 } \\
\text { (親) }\end{array}$ & $\begin{array}{l}\text { 日本語母 語 話者 } \\
\text { (疎) }\end{array}$ & $\begin{array}{l}\text { 中国語母語話者 } \\
\text { (疎) }\end{array}$ \\
\hline 同感 & 笑い & 同感 & 笑い \\
\hline ポジティブ評価 & 同感 & 笑い & $\begin{array}{l}\text { 同感 } \\
\text { ポジティブ評価 }\end{array}$ \\
\hline
\end{tabular}




\section{許 夏玲：会話参加者によるFTA 軽減ストラテジーの使用実態}

一日本語母語話者と中国語母語話者の場合-

（19）日本語母語話者（疎）【同感】（ポジティブ）

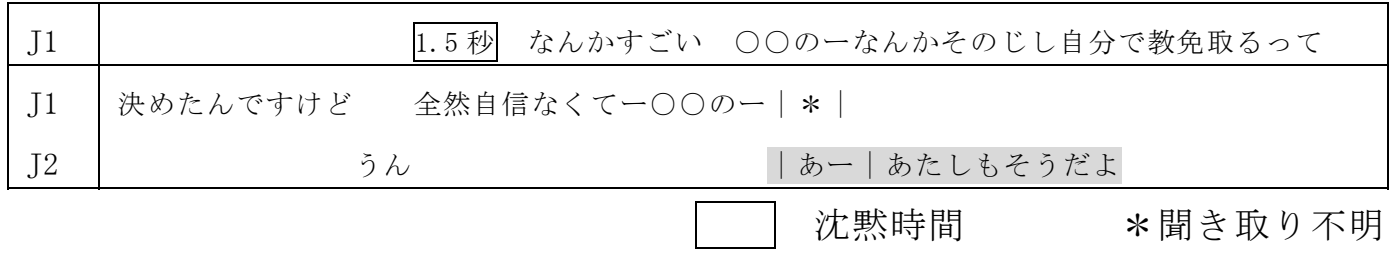

\section{表 8 冷やかしの場合}

\begin{tabular}{|l|l|l|}
\hline 日本語母語話者（親） & 日本語母語話者（疎） & 中国語母語話者（疎） \\
\hline 同感 & $\begin{array}{l}\text { 同感 } \\
\text { 笑い }\end{array}$ & ポジティブ評価 \\
\hline
\end{tabular}

（20） 中国語母語話者（疎）【ポジティブ評価】（ポジティブ）

\begin{tabular}{|c|c|c|}
\hline $\mathrm{C} 1$ & 然后现在我们同学嘛 他们都是找工作啊 & 要不女生 就是愁嫁了笑 $<$ 笑 $>$ \\
\hline $\mathrm{C} 2$ & & 那么早嘛？[そんなに早いの？] \\
\hline
\end{tabular}

\section{7. まとめと今後の課題}

考察の結果、FTA の状況におちいる際、笑い（両言語母語話者）及びフィラー（日 本語母語話者）が多く用いられることがわかった。笑いは、会話参加者の負担や 面目を失いそうな状況を和らげる機能を持ち、フィラーは、言いよどみの位置（文 頭や文中）に多く現れ、話し手の応答に対寸る時間を稼ぐ機能を持つと考えられ る。FTAのような状況に用いられるフィラーは、相手への応答を逸らし、自分の発 話権をさりげなく相手に譲る効果がある（例 18）。笑いもそのような機能を持って いる。日本語会話では、FTA の状況におちいる際のフィラー表現の運用、笑いや話 題回避のストラテジーによるフェイスへの負担が軽減でき、かつ現会話を維持し ていくことができるなど、これらのストラテジーを学習者に気づかせる必要があ ると考えられる。今回は、日本語母語話者同士及び中国語母語話者同士の親疎各 2 組、合計 8 組の会話データに基づいて考察した。表現の使用に関しては、個人差 があるという点は否めない。今後、会話データを多く収集し、研究を深めていき たいと思う。 
本稿は 2012 年社会言語科学会第 29 回大会にて発表した内容を修正したもので ある。 
許 夏玲：会話参加者による FTA 軽減ストラテジーの使用実態

一日本語母語話者と中国語母語話者の場合-

\section{参考文献}

三牧陽子 (2008)「会話参加者による FTA バランス探求行動」『社会言語科学』第 11 巻, 第 1 号, pp.125-138

Brown \& Levinson. 1987. Politeness : Universals in language usage. Cambridge University Press.

Ikeda, Tomoko. 2003. “The Organization and Functions of Laughter in a Japanese

Face-to-Face Interaction”. 『社会言語科学』第 6 巻, 第 1 号, pp. 52-60

Leech, G. N. 1983. Principles of Pragmatics. Longman.

Levinson, S. 1983. Pragmatics. Cambridge : Cambridge University Press.

\section{会話資料}

許 夏玲 (2010)「話し言葉の研究 CD-ROM」会話データベース

\section{付加資料（例文の日本語訳）}

(6) 中国語母語話者（疎）

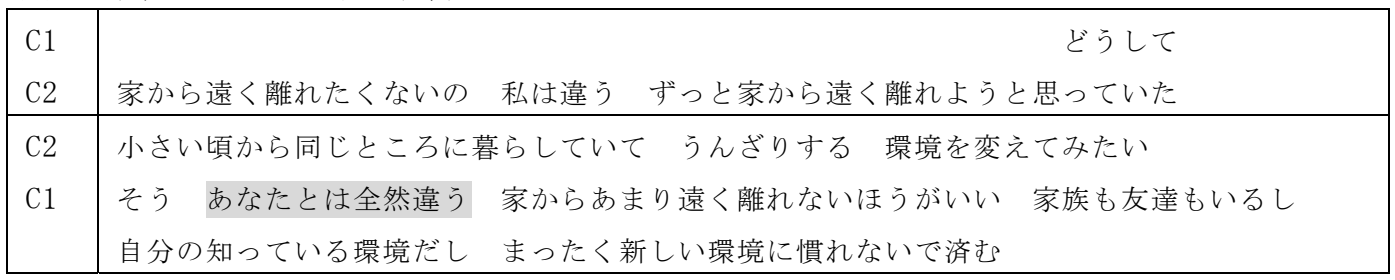

（7）中国語母語話者（親）

\begin{tabular}{|c|c|}
\hline $\begin{array}{l}\mathrm{C} 1 \\
\mathrm{C} 2\end{array}$ & $\begin{array}{c}\text { そうよ 母に言ったの わたし あったかパンツなんて知らないよね } \\
\text { うん }\end{array}$ \\
\hline $\mathrm{C} 1$ & そうそうそう〈笑い〉あったかパンツ \\
\hline $\mathrm{C} 2$ & あったかパンツはズポンの中に着るの〈笑い〉 \\
\hline
\end{tabular}

（10）中国語母語話者（親）

\begin{tabular}{|c|c|c|c|}
\hline $\mathrm{C} 1$ & \multicolumn{2}{|c|}{ えっ? } & 高校で 15 日間だけだった＼cjkstart笑い> \\
\hline $\mathrm{C} 2$ & ずっと高校だったの㸚 & ずっと高校で教えていたの & もうやめたの? \\
\hline $\mathrm{C} 1$ & やめた＜笑い $>$ & <笑い> & \\
\hline $\mathrm{C} 2$ & \multicolumn{2}{|c|}{ すごい<笑い> } & \\
\hline
\end{tabular}


（12）中国語母語話者（疎）

\begin{tabular}{|c|c|c|c|}
\hline $\begin{array}{l}\mathrm{C} 1 \\
\mathrm{C} 2\end{array}$ & アパートを借りるのが大変だった それから勉強 & 彼らも私たち & 交換留学生と同じコースで \\
\hline $\mathrm{C} 1$ & \multicolumn{3}{|c|}{ もう 何のためだったのか このように 自分もよくわからない } \\
\hline $\mathrm{C} 2$ & & そう & 交換留学とここに住んでいて \\
\hline $\mathrm{C} 1$ & \multirow{2}{*}{$\begin{array}{l}\text { うんうん } \\
\text { ここのビザを取るのとちょっと違う感じがする } \\
\text { 体験してみるだけで }\end{array}$} & \multirow{2}{*}{\multicolumn{2}{|c|}{$\begin{array}{l}\text { うん } \\
\text { 交換留学ってどうせここに来てちよっと }\end{array}$}} \\
\hline $\mathrm{C} 2$ & & & \\
\hline $\mathrm{C} 1$ & そう 私はそうなのく笑い> & そうそうそう & そういうこと \\
\hline $\mathrm{C} 2$ & \multicolumn{3}{|l|}{1 年でもう帰るく笑い> } \\
\hline
\end{tabular}

（13） 中国語母語話者（疎）

\begin{tabular}{|l|l|l|}
\hline $\mathrm{C} 1$ & \\
$\mathrm{C} 2$ & それから なかなか見つからなくて 最後は 先輩 先輩が働いていたお店で それから \\
& 知っている店長にちょっと紹介してくれただけ \\
\hline C1 & わたし \\
C2 & それから すぐアルバイトができた 不器用でけっこう恥ずかしかったと思う \\
\hline C1 & 私は自分で探したの 駅からすごく遠く離れていて 歩いて 20 分もかかるの \\
\hline
\end{tabular}

（15）中国語母語話者同士（疎）【話題回避】（ネガティブ）

\begin{tabular}{|l|c|c|}
\hline $\mathrm{C} 1$ & 1 年でいい 将来進学しなくても仕事に来られるし \\
$\mathrm{C} 2$ & 1 年で \\
\hline $\mathrm{C} 1$ & \multicolumn{2}{|c|}{ 私は将来もう進学したくないく笑い〉もう勉強したくない } \\
$\mathrm{C} 2$ & 〈修士課程中の自分と違って> $\quad<$ 笑い> & どこ出身? \\
\hline
\end{tabular}

（17）は（10）と同じ例文である。

（20）中国語母語話者（疎）【ポジティブ評価】（ポジティブ）

\begin{tabular}{|l|l|l|}
\hline C1 & $\begin{array}{l}\text { それから今同級生達 もう仕事を探し始めているの } \\
\text { むわく笑い> }\end{array}$ \\
C2 & そんなに早いの? \\
\hline
\end{tabular}

